\title{
The Many Facets of Chinese Nationalism
}

Jean-Pierre Cabestan

\section{OpenEdition}

Journals

Édition électronique

URL : http://journals.openedition.org/chinaperspectives/2793

DOI : 10.4000/chinaperspectives. 2793

ISSN : 1996-4617

\section{Éditeur}

Centre d'étude français sur la Chine contemporaine

Édition imprimée

Date de publication : 1 juin 2005

ISSN : 2070-3449

\section{Référence électronique}

Jean-Pierre Cabestan, "The Many Facets of Chinese Nationalism », China Perspectives [En ligne], 59 may - june 2005, mis en ligne le 01 juin 2008, consulté le 28 octobre 2019. URL : http://

journals.openedition.org/chinaperspectives/2793; DOI : 10.4000/chinaperspectives.2793

Ce document a été généré automatiquement le 28 octobre 2019

(c) All rights reserved 


\title{
The Many Facets of Chinese Nationalism
}

\author{
Jean-Pierre Cabestan
}

1 Chinese nationalism is a more ambiguous reality than it might seem. Its existence cannot be denied. It has great power and intensity, as shown over the last few years by the demonstrations against the American bombing of the Chinese embassy in Belgrade in May 1999, the EP3 incident in April 2001, the denunciation of the Japanese Prime Minister's visits to the Yasukuni Shrine, the virulent criticisms of Taiwanese leaders, from Lee Teng-hui to Chen Shui-bian, and, more recently, the ambition to make China not only a great economic and military power but to surpass the United States as the greatest power in the world. Nationalism seems today to be the most widely-shared value both in Chinese society and in the government, which is perfectly aware of this, and has repeatedly instrumentalised it with the aim of strengthening its hand in the face of its foreign partners and also of preventing any "peaceful evolution" of the regime towards democracy.

2 Yet at the same time, motivated by self-interest, many international actions by the Peking government, and many expressions of society, have remained impervious to this feeling of nationalism. The opening up of the Chinese economy and society to the outside world, the establishment of diplomatic and trade links with those powers who had once "humiliated" China (the United States, Japan, Great Britain, Germany, France, etc.), Peking's accession to the World Trade Organisation (WTO) and the acceptance (provisional, it is true) of a form of status quo in the Taiwan Strait, are evidence of a certain "bringing under control" of nationalist emotions which can affect government circles and the intellectual elite. Similarly, within Chinese society, the pursuit of individual success, the desire-and perhaps even more the possibility-to become rich and to improve one's standard of living, the increasing power of provincialism and localism, the fascination with an America which is both powerful and prosperous, the attraction of a modernity which is often synonymous with the "American way of life", as well as a general curiosity about a long forbidden outside world - as shown by the growth of Chinese tourism abroad - and the emigration of millions of Chinese towards 
the developed world, are all evidence, if not of an absence, at least of a relative weakness of nationalism. This attitude has led a number of writers to put forward the concept of "pragmatic nationalism"1.

Moreover 9/11 and the worldwide war against terrorism have contributed to creating solidarities between Chinese and Western governments, solidarities which have attenuated, at least up to the spring of 2005, the most spectacular and extreme manifestations of Chinese nationalism. Finally, the last ten years have brought to light a spectrum, wider than one might previously have expected, of international behaviour on the part of both Chinese government and society, putting into perspective the nature and extent of Chinese nationalism and making it possible to distinguish more clearly between ordinary times and the brief-but intense and emotional-moments of more or less spontaneous manifestations of nationalism.

While, for historical reasons, Chinese nationalism is in many ways specific, because it is based on what is perceived as past humiliation (xiuru), it has shown since the beginning of the modern era, which is to say since the Opium War of 1840, a profound feeling of insecurity. However, beyond this feeling of insecurity, several forms of nationalism co-exist in this country, as they do in any other.

It is first of all an official nationalism, inspired by communist ideology and the preoccupation of the Communist Party (CP) with maintaining its monopoly of politics: this is synonymous in China with "patriotism".

6 It is also a "revanchist nationalism" with racist tendencies, which is disseminated in society by the most xenophobic elements among the Chinese elite-in particular the "New Left"-which rely on popular ignorance of foreign countries and the traditional mistrust towards them, to spread their ideas. Based more on the need to wash away past humiliations than on a rational analysis of reality, influenced by communist patriotism but going beyond it, this form of nationalism was particularly influential in the second half of the 1990s. Its manifestations more frequently took the form of antiforeign emotions and violence than of structured discourse or coherent action. Stimulated by the elites close to government circles, it was once again instrumentalised by the latter in the spring of 2005.

7 One may well wonder if there is not another form of Chinese nationalism, a nationalism which derives its legitimacy both from cultural specificity and from current Chinese economic and social realities, without however rejecting foreign influence out of hand. While seeking to modernise China and to make it regain the place and influence which are its due in the international community, while preserving its culture, this nationalism seeks to be less aggressive and more peaceable, showing a desire to favour convergence, in particular political convergence, with the rest of the world. Symbolised by the concept, favoured by Hu Jintao, of China's "peaceful rise", can this nationalism eventually give birth to a democratic nationalism, at once measured, open, and concerned with defending not only the interests of the Chinese nation but also those of the men and women who belong to it? Is not this nationalism the only one capable of expressing a real ideological consensus in society, far from the manipulations of political and intellectual elites driven above all by ambition and the struggle for power? The elitist nationalism of a great power dispossessed and humiliated

8 It is widely accepted that Chinese nationalism took form only as a reaction to the shock of forced contact with the West, after the Opium War of 1840. It is true that before this historic turning-point, China was much more an empire than a Nation State, a 
civilisation and a culture dominated by one race $(\mathrm{zu})$-the Han-rather than a society brought together by a national project, and even less so by a modern citizenship. This is why several sinologists have contrasted the old "culturalism" with the nationalism of the Chinese after $1840^{2}$. In fact, despite earlier contacts with the outside world, in particular with Russia, it is this emblematic event which truly transformed the Chinese Empire into a modern State, and China into a Nation, thus confirming the theses of Ernest Gellner and Eric Hobsbawm on the decisive role played by the state in the construction of the nation and consequently on the formation of nationalism ${ }^{3}$.

However the main specificity of imperial China may lie elsewhere: many non-Western societies did not have the characteristics of the old European nations (in particular France and England), while being brought together by clear and specific racial origins, in short an ethnic or "objective" nationalism, which, in contact with the West, could only be exacerbated. On this last point, Japan and Korea come to mind-in the languages of these countries, as in Chinese, the idea of nationalism (minzuzhuyi), introduced in the nineteenth century includes the idea of race (minzoshugi in Japanese and minjokchuyi in Korean) $)^{4}$. These nations therefore also constituted, in their own ways, "imagined communities", to use Benedict Anderson's classic formulation ${ }^{5}$. Moreover, also in the West, "subjective" nationalism, as a feeling and a movement, is a phenomenon scarcely older than modern Chinese nationalism, brought about directly by the consolidation of states, the drawing of frontiers and the ideological changes of the eighteenth century ${ }^{6}$.

The specificity of Chinese nationalism stems from the almost permanently dominant position occupied by the Chinese Empire within the world with which it maintained relations prior to 1840. After its fall from the pedestal, the impact of the West was all the more strongly felt, the humiliation provoked all the more profound, China's resistance to outside ideas all the stronger, causing the failure of numerous reforms at the end of the Manchu era, at the very moment when Meiji Japan, having become Europe's pupil after having been China's, was modernising on an economic level as well as in political and institutional matters. We know that Chinese nationalists, and the Communist Party in particular, continue to accuse Western imperialism of being the main instigator of these failures, in particular by imposing inequitable treaties on their country, whereas historiography as a whole has shown that the weakening of the Empire predated 1840, and was due to a number of internal causes (in particular the doubling of the population between 1700 and 1800). What is interesting to focus on here is the foundational dimension of the trauma of 1840 in the debate on Chinese nationalism. Since then the debate has been between those who favoured resistance to the West and the partisans of modernisation by the introduction, not only of Western sciences and techniques, but also of Western ideas, modes of organisation (political institutions and law) and of management.

11 The second specificity we would venture to put forward is the essential role played in China by the political and intellectual elites in the formation of contemporary nationalism. As both Wilfred Pareto and Roberto Michels have shown, the role played by the elites in the conceptualisation, manipulation and propagation of this ideology is universally important. Despite the relevance of the work of both Pierre Birnbaum and Ezra Suleiman on the elites in France, this influence tends to grow as a particular regime moves away from democracy and leans towards authoritarianism. The elitist character of Asian and especially Confucian societies, for example those of Japan and 
Korea, gives the elites a specific influence in this undertaking. As we shall see, certain nationalist movements which appeared in China after 1840-the Taiping and the Boxers-were not entirely the preserve of the "counter-elites" but of social strata who perceived foreign ascendancy-respectively the Manchu and the Westerners-to be the source of their problems. The hypothesis we seek to put forward here, however, and which seems to be borne out in the People's Republic today, is that of the virtual monopoly exercised by the elites in the formation of nationalism, and the low level of interaction between them and the rest of society, which, structured as it is around personal and family obligations, remains, except in times of major crisis (even in the case of the Sino-Japanese war) relatively impervious to this ideology, and especially to its translation into action ${ }^{7}$. A reflection of the distanced relations between society and the state in China, this gap is much less obvious elsewhere, particularly in Japan or in Korea. This specificity favours a more energetic manipulation of nationalism by the elites, particularly those which have privileged interaction with government.

The diversity of nationalist responses to China's problems

The apparent binarism of the choices put forward by the Chinese elites after 1840either resisting the West or learning from it-did not lead to an inevitable monopolisation of nationalism by the detractors of the West. On the contrary, what is shown by a century and a half of contemporary Chinese history is the great diversity of discourses and political and economic projects that the country produced. It is enough to briefly recall the debates among the elites at the end of the Manchu era (1644-1911) and the way in which these structured the political forces in the republican period (1912-1949) to be convinced of this.

13 Constrained against its will to open up, subjected to the regime of "inequitable treaties", of zones of influence and of foreign concessions, China after 1840-and once again its elites above all-could not be other than unanimously nationalist and antiWestern. But at the same time, this nationalism was not turned against the European powers only: it was also aimed at the "foreign", which is to say non-Han, power of the Manchu dynasty, and militated for the restoration of the Ming; as was shown by the Taiping rebellion (1851-1864), it could both draw inspiration from Western religions, in this case Christianity, and display profound xenophobia. After the humiliating military defeat against Japan in 1895, it was fuelled by both enduring jealousy towards that country and a strong determination to learn from it. Above all, nationalist reaction to Western domination was plural from the beginning.

At one end of the spectrum, under the impact of the West and of the "Break-up of China" in 1898, which is to say the race for concessions, was the formation of a rural and populist "primitive nationalism" based on an "ethno-cultural awareness" of which the Boxers rebellion in 1900 was the best-known manifestation ${ }^{8}$. This rebellion, moulded by religions and popular millenarian beliefs, consolidated a xenophobic nationalist tradition, racist and above all anti-Western, as well as anti-Christian. Sanctified by the Communist Party, the Boxer movement experienced a certain extension during the Maoist period, particularly during the Cultural Revolution (even though the Red Guards, often issued from the Nomenklatura, can be considered a "counter-elite", anxious to instrumentalise, for uniquely political and personal purposes, their rejection of the outside world). Although the manifestations of nationalism which have appeared since the reopening of China in 1979 have never equalled that degree of fanaticism and xenophobia, one cannot bank on the 
disappearance of this tradition, particularly among the elites. Indeed, despite a certain evolution in historiography, not only does the present Chinese government continue to consider the Boxers as nationalist heroes and to propagate this idea in the country's school textbooks, but the many who have been pushed aside by economic growthwhile certain sections of the elite like to manipulate them and use them in the service of their political ambitions-might well in future find in the expatriate population in China the most obvious scapegoats for their misfortunes.

Right next to this movement lies an "instrumentalist" nationalist tradition which has constantly sought to introduce into China only those "recipes" of the West which are likely to strengthen the state with the exclusive aim of enabling it better to resist both domination and ideas from outside. Personified in the nineteenth century by Zhang Zhidong, whose aim was to adopt only the sciences and techniques of Europe in order to maintain "Chinese knowledge as substance" (zhongxue wei ti), and by the statesman Li Hongzhang, this conservative tradition advocated the maintenance of an unalloyed Confucianism, opposed to any opening to the West. It contributed to the failure of the prudent reforms of the Hundred Days in 1898, launched by Kang Youwei and Liang Qichao. It also influenced a number of Chinese reformers and constitutionalists at the beginning of the twentieth century, who conceived the law and political institutions more as weapons for the consolidation and modernisation of the state than as comprehensive values aimed at guaranteeing the rights of citizens in the face of the state .

16 This tradition was long maintained by the Communist Party. In fact, the foundation of the People's Republic in 1949 allowed this kind of nationalism, officially anti-Confucian and modernising, but in reality conservative and favourable to the maintenance of a traditional rural society, to impose itself for over thirty years. The alliance with the Soviet Union, and then the falling-out between the two countries, led Mao Zedong's China to accept Western techniques and modes of organisation only extremely sparingly, establishing a de facto nationalist isolation which seemed to link up with the Empire before 1840. While this current of thought is weaker now, it would be wrong to think that it has disappeared, for it is present within the Communist Party of Deng Xiaoping, Jiang Zemin and in particular Hu Jintao, and helps to explain the Party's persistent ambiguity towards the West ${ }^{10}$.

17 A third current of thought is based on what Yves Chevrier calls "the modernising nationalism of the reformist elite". Its first and principal promoter at the end of the nineteenth century was probably Kang Youwei, one of the architects of the Hundred Days reforms. While he favoured the study not only of the techniques but also of the ideas of the West, Kang was nevertheless a supporter of a renovated Confucianism. While he hoped, in 1898, to introduce reforms in three years, particularly in the institutions, which Meiji Japan had applied over the course of thirty years, he had no intention of calling into question his country's Confucian legacy, but sought, by means of reforms decided on high, to establish a utopian consensus, the great unanimity (datong). Today one is struck by the similarities between Kang's ideas and plans, and those of Deng Xiaoping, Jiang Zemin and Hu Jintao. All three of these leaders are unquestionably modernisers and reformers. However, the official rehabilitation of Confucianism over which they presided from 1979 on, their exaltation of traditional morality and of virtue (de), in the same way as the "socialist rule of law" and the protection of human rights, their determination to maintain the leadership role of the 
Communist Party, which they see as the only guarantor of social consensus (in particular through the theory of the "three representations"), betray a nationalist resistance to the globalisation of ideas and to democratisation ${ }^{11}$. While it is less antiWestern than previous ones, this form of nationalism seeks nonetheless to contrast the path chosen by China with that followed by the West. It is therefore frequently instrumentalised in order to reinforce the unity of society around the political establishment, and to defend the international interests of the country.

Lastly there does exist in China a form of nationalism that is broadly pro-Western. Despite his ambiguities, Yan $\mathrm{Fu}$ (1852-1921) is one of the first and the most representative of this trend ${ }^{12}$. Having introduced the most important Western political thinkers to his compatriots (including John Stuart Mill and Montesquieu), Yan held up the British parliamentary system as a model for his country. While he influenced the communists and Mao Zedong in particular, he left his mark above all on the democratic nationalist tradition embodied by Sun Yat-sen, Hu Shi and Lu Xun. It is true that Yan $\mathrm{Fu}$, and then Sun Yat-sen felt that they had to move forward prudently and prepare the people by education, and therefore by what were once again Confucian methods, for democracy. Thus $\mathrm{Yan} \mathrm{Fu}$, towards the end of his life, gave his support to the dictatorship of Yuan Shikai (1912-1916) and Sun Yat-sen, after the failure of the revolution in 1911, conceived of the establishment of a constitutional government (xianzheng) in three stages-which would have to be preceded by a military government (junzheng), and then by political control (xunzheng) of the Kuomintang (KMT) over society.

19 Nevertheless, while it sought to build on those aspects of Chinese tradition that could favour the modernisation of the country, this form of nationalism was largely inspired by the West. Sun Yat-sen established, at the beginning of the republican period, the "three principles of the people": nationalism (minzuzhuyi), democracy (minquan) and the well-being of the people (minsheng). He also proposed the establishment of democratically elected political institutions-the five Yuan or Councils-which combined the separation of the three powers of the Enlightenment (the legislative, the executive and the judiciary) with the Chinese administrative tradition (the powers of examination, stemming from the imperial competitive examinations, and of control, inspired by the censorship). While his successors, particularly Chang Kai-shek, were for a while attracted by the Soviet Union's anticolonialism or Germany's militarism, they turned to the West above all in order to modernise their institutions, their laws, their economy and their education system. As an active participant in the nationalist movement of the Fourth of May 1919, which is to say the protests of the elites and of the students against the decision contained in the Treaty of Versailles to transfer to Japan the former German possessions in China, the Kuomintang largely contributed to the dismantling of the concessions, which became definitive in 1943, and more generally to the reintegration of the Chinese nation among the world's great powers. It was partly thanks to these efforts that in 1945, at the end of the Second World War and the Sino-Japanese conflict, China, with the support of the United States, became a permanent member of the UN Security Council.

20 It is clear that, giving priority to the strengthening of the central government in Nanking, which was the capital of the Republic of China from 1928, and to the subjugation of local potentates and of the communist rebellion, Tchang Kai-shek dithered over launching a hopeless counterattack against Japan's territorial violations, 
which allowed Mao and his partisans to appear in the eyes of many Chinese, and above all of important sections of the Chinese elite, as the only upholders of the nationalist cause. Having taken refuge in Chungking from 1938 to 1945, the Kuomintang government largely abandoned the political territory of the occupied zones to the Communist Party, which reinforced the identification of the Party with resistance to the Japanese (and allowed Mao to extend his hold over that part of the country). The Kuomintang remained nevertheless highly nationalist, having sacrificed its best officers to the defence of Nanking in 1938 and later negotiating inch by inch with the Allies, and particularly with the Americans, the return of the Chinese possessions which had been snatched by Japan, among them Taiwan (at the Cairo Conference of 1943). The Sino-Japanese war did nevertheless favour the political victory in China in 1949 of the conservative nationalism, totalitarian and with xenophobic tendencies, of the Communist Party over the liberal, constitutional and pro-Western, if not yet democratic nationalism of the post-war Kuomintang.

21 This historical framework is important because these four main nationalist movements are still represented in the People's Republic. Thanks to the reforms of 1979, and then the clamp-down which followed the Tian'anmen massacre in 1989, the respective influence of these various facets of Chinese nationalism has evolved. But as we shall see, this evolution is far from over. Because of the slow death of communist ideology under the successive batterings of the reforms, of the opening-up and of the collapse of the Soviet Union, the leadership of the Communist Party has been increasingly tempted since 1989 to instrumentalise the anti-Western and especially anti-Japanese dimensions of Chinese nationalism. Certain segments of the Chinese elites have used this ideological movement to strengthen either their influence over the government or their opposition to the current system. The partial withdrawal of control over intellectual debate has favoured the reappearance of several competing forms of nationalism, bringing to light once again the fundamentally plural character of this phenomenon, particularly among the elites.

Nationalism in China today

Nationalism has always formed a part of the official discourse of the Chinese Communist Party. However, for reasons which stem from its ideology and from its links with the Communist International, it preferred for a long time the idea of "patriotism" (aiguozhuyi) which was supposed to be more easily reconcilable than nationalism properly speaking (which had once been denounced by Mao and his comrades) with the "proletarian internationalism" which the Party claimed to embrace ${ }^{13}$. The collapse of the international communist movement and the dismemberment of the Soviet Union did not call the idea of patriotism directly into question. The authorities in the People's Republic still today consider as "patriotic" any Chinese person who shows allegiance to the state, renders it service and accepts the directives of the Communist Party, whether they are communist or not. Thus Peking continues to award this honorary "seal of quality" to many overseas Chinese who have chosen the mainland over Taiwan. However, since Tian'anmen and the collapse of the Soviet Union, the idea of nationalism has gradually regained its place in Communist Party discourse, clearing the way for the expression among the intellectual elites of a "new nationalism", more populist and autonomous, which, since the mid-1990s, has gone beyond the bounds of the nationalism set by the Party ${ }^{14}$. This evolution has led leadership circles in return to adopt an ambivalent attitude to this trend, hesitating between instrumentalisation and 
control, particularly with the aim of maintaining more margin for manœuvre on the international level.

The increase in the power of state nationalism after Tian'anmen

The increase in the power of nationalism after Tian'anmen has been multidimensional from the beginning. There was first of all the irruption of a state nationalism which some dubbed "nationalism of substitution" ${ }^{15}$, because to a large extent it replaced a communist ideology which had shown its futility and above all its inadequacy in the face of the economic and social realities which the Communist Party was allowing to take root in China. Appearing in 1991, this form of nationalism was part of the transformation of the Communist Party into a Ruling Party (zhizhengdang), offering daily proof of its management abilities and presiding over the destiny of a "great country" (daguo), whose power is to grow irresistibly and thus eventually overtake the United States.

While this state nationalism was, for a period in the 1990s, attracted by "Asian values", today it is seeking above all to find in the Chinese Confucian and Imperial tradition the foundations of a legitimate national territory, of an authoritarian national identity and of government by virtue or by benevolence (renzheng). On the foreign level, this form of nationalism favours diplomacy and a security policy entirely based on national interests (guojia liyi), an idea which had been absent from the discourse of the Chinese Communist Party before, and the reconquest of the Manchu Imperial area (in particular Taiwan). It is above all more often used by the authorities in Peking, who always seek to place their partners in a position of inferiority, for example by constantly alluding to their five millenia of history and culture, or to strengthen their hand in negotiation, by throwing into the balance the supposed nationalist feelings and even anger of their compatriots.

Having targeted, after Tian'anmen, Western countries as a whole, who were suspected of favouring China's "peaceful evolution" (heping yanbian) towards "bourgeois democracy", this state nationalism then concentrated its attacks on two countries which are close to China and have a particular interest in the question of Taiwan: the United States and Japan. The private visit by the Taiwanese President Lee Teng-hui to the United States in 1995 unleashed an unprecedented official offensive against Washington centred on the theme of the inevitability of the rebel island's reunification with the "Mother Country"16. The perspective of the return of Hong Kong (1997) and Macau (1999) was not foreign to this instrumentalisation of the question of Taiwan. However, these attacks against the United States, which was accused of seeking to hamper the satisfaction of China's legitimate demands, were part of an increase in bilateral tensions, which were themselves exacerbated by a variety of frictions ${ }^{17}$.

During the same period, the Chinese Communist Party intensified its criticisms of Japan, stigmatising it for a whole range of reasons: on the one hand for its desire to strengthen its security links with the United States (shown in particular by the adoption in 1997 of new Guidelines for US-Japan Defence Co-operation and in February 2005 of a declaration which identified Taiwan as a common strategic objective) and to enhance its relations with Taiwan, and, on the other hand, for its persistent refusal to present a "sincere apology" for the crimes it committed during the Second World War, to put an end to the visits to the Yasukuni Shrine where are preserved the funerary stones of the 2.5 million soldiers killed during the Second World War, among them 14 war criminals, to exercise more control over the publishing of history textbooks with 
revisionist tendencies, and finally, to yield on the question of the Senkaku (Diaoyutai) archipelago. The presentation by Tokyo of a written apology to Seoul in 1998 was the occasion for an official offensive by Peking, aimed at obtaining the same commitment (when a verbal apology had already been made in 1995). However, because Jiang Zemin did not wish to promise to put an end to Chinese criticisms of the Japanese government's attitude to the events connected with the war, the latter refused to accede to his demand, provoking, after the failure of Jiang's visit to Japan in 1998, a further salvo of nationalist attacks from the Chinese Communist Party.

Fuelled by certain intellectuals who chose to serve the government after Tian'anmen, such as $\mathrm{He} \mathrm{Xin}^{18}$, this state nationalism has also favoured the irruption of a populist nationalism whose most extreme manifestations have recalled the xenophobia and anti-Western attitudes of the "primitive nationalism" at the end of the nineteenth century.

A new populist nationalism in China

The central place occupied by nationalism in the ideology of the Chinese Communist Party since 1989 has favoured the expression, particularly among the intellectual elites, of an autonomous popular nationalism with populist tendencies, beginning in the second part of the 1990s, a period marked by the crisis in the Taiwan Strait (1995-1996), the American bombing of the Chinese embassy in Belgrade (1999) and more recently the demonstrations of April 2005 against Japan. The adjectives "popular", "autonomous" and "populist" deserve explanation. To what extent does this form of nationalism reflect the feelings of significant sections of Chinese society? Is it really autonomous from the state nationalism propagated by the Chinese Communist Party? In a country where the state tightly controls the media and organised demonstrations, is not this autonomy inevitably limited and subject to manipulation by the government, or certain sections of the government? Are the supporters of this form of nationalism tempted to seek the support of society by criticising what they perceive to be a series of weaknesses and compromises on the part of the government, and of the official elites, in the face of the outside world?

The 1980s were not without autonomous nationalist movements. For example, the student demonstrations against the revision of Japanese school textbooks in 1985 were already aimed at influencing government policy towards Japan (and in fact contributed to the fall of Hu Yaobang, a convinced supporter of reconciliation with Tokyo). But generally speaking, Chinese society, fascinated by the discovery of the outside world, was much more bent on learning from the West, envying its prosperity and seeking its freedom, than on rejecting it, distrusting it or criticising its dominant position. Moreover debates on foreign policy were still highly regulated, restricting any autonomous and public participation by society, and above all by the intellectuals, in them.

Things changed gradually after Tian'anmen. It was probably the publication in 1994 of a book by Wang Shan, a former Red Guard who had become a writer, Looking at China Through The Third Eye, which heralded the re-emergence in China of a form of nationalism and of critical foreign policy discourse which were in fact autonomous and populist. Worried by the growing gaps in society brought about by the reforms and nostalgia for the Maoist period, Wang believed that only an autocratic and elitist state could allow China to remain stable, to develop successfully and to become a great power again. In parallel he developed a discourse opposed to liberalism, and in 
particular to the United States, which he accused of having encouraged and supported the Beijing Spring of 1989, and of seeking to overthrow the Chinese Communist Party, because, among other reasons, it possessed nuclear weapons. However, as if to reassure himself, and following the discourse of state nationalism, he was of the opinion that America was in decline and that the future belonged to the East ${ }^{19}$.

At the time these opinions were still in a minority among the intellectual elites and were carried by few publications, apart from a new journal, Strategy and Management (Zhanlüe yu guanli), which, launched at the end of 1993 with the support of major leaders in the Communist Party and in the army (among them Generals Xiao Ke and Zhang Aiping), had begun to develop, in the writings of authors such as Yan Ping and Wang Xiaodong, a prickly, aggressive and populist nationalism.

It was the crisis in the Taiwan Strait which probably contributed the most to the rise of populist nationalism in Chinese society. By 1994-1995, several opinion polls showed obvious popular support for a pro-active and aggressive policy of reunification with Taiwan and a clear increase in anti-American feelings among young Chinese. Carried out in a closed society where outside viewpoints are systematically distorted or censored, these polls produced results that are clearly questionable. They nevertheless directly inspired a number of nationalist books published after 1996, of which the bestknown was China Can Say No (Zhongguo keyi shuo bu). Written by young intellectuals (Qiao Bian, Zhang Zangzang and Song Qiang) based on the model of Japan Can Say No by the far-right member of parliament Shinaro Ishihara, this book was followed by many others which, often for primarily commercial reasons, sought to exploit this new "seam".

These intellectuals had managed to pick up the feelings of a fairly substantial part of public opinion and to systematise them into a discourse which, without contradicting that of the Party, went beyond it. Nevertheless these nationalist tracts, which demonised the United States, were produced by a relatively small elite. Most of the authors were young intellectuals who were brought together in what the Chinese press then called "The No Club" (shuo bu julebu), with about ten members. Among them at the time were Liu Kang and Li Xiguang who, in December 1996, published Behind The Scenes of The Demonisation of China (Yaomohua Zhongguo de beihou), a vitriolic denunciation of the American media ${ }^{20}$.

The outrageous statements, the idea of a Western, and particularly an American plot aimed at preventing China from developing itself and thus becoming stronger, as well as the determination-and the certainty-displayed to raise China to the rank of most powerful nation in the world and thus to put an end to American hegemony, all these themes expressed, within the Chinese elites, both a growing awareness and a deep feeling of insecurity. An awareness, related to the 1980s, that the West could not provide all the answers to China's problems, and a feeling of insecurity in the face of foreign criticism of their country, and especially the dangers of economic failure or of social instability which they criticisms alluded to.

Fascinated by Western success during the first decade after opening up, these intellectuals were now tempted to perceive in the West, if not always the cause of their ills, at least the main obstacle to the realisation of their country's destiny as a great power. This is why, worried by the implications of the globalisation of the Chinese economy, they were often hostile to China's accession to the World Trade Organisation (WTO), and critical of the supposed weakness of their government during the 
negotiations. Lastly, they developed the idea that because of the antiquity of their civilisation, the greatness of their culture, and the intrinsic qualities of the "Chinese race" (hanzu), their country could legitimately claim the first rank in the world which the Americans, whose culture was constantly presented as young and superficial, had usurped by taking advantage of China's temporary weakness. It was thus a question for China, by rising above the United States, of washing away the humiliation inflicted by the West (and Japan) from 1840 onwards.

One can obviously see in this discourse the direct influence of the domestic communist propaganda that can be found, for example, in school textbooks. This has always more accurately reflected the position of the Communist Party leadership than the more civilised discourse that it broadcasts on the international scene, and is moulded by a deep feeling of superiority (which classically conceals an obvious feeling of inferiority). The same is true of the nationalism propagated within the armed forces, some studies of which have revealed its deeply anti-American and anti-Japanese character ${ }^{21}$. Nonetheless, nationalist intellectuals developed anti-American, anti-Japanese, antiWTO, and sometimes racist ideas that manifestly went beyond even the internal discourse of the Peking authorities. It is true that the authorities allowed these theses to be published and broadcast. In this sense, one cannot help suspecting a certain collusion or, as we said earlier, a temptation to instrumentalise this extremist discourse, which allows the Chinese government to appear in the eyes of the world as supporting a moderate, tolerant, or so to speak "centrist" form of nationalism. The fact remains that Wang Xiaodong, Song Qiang and others like them developed from this period onwards an autonomous strategy and position which largely contributed to the spontaneous demonstrations in May 1999, protesting against the accidental bombing of China's embassy in Belgrade by NATO forces, and to the violent and probably less spontaneous demonstrations in April 2005 against Japan ${ }^{22}$.

The demonstrations in May 1999: a turning point in Chinese nationalism?

Much has been said and written about these demonstrations. With hindsight, one can first of all state that there was then a very clear convergence between the position of the government and the feelings expressed in the streets. The reasons for this encounter were, however, far from being identical. On one side the Chinese Communist Party reacted all the more strongly to the bombing because it had taken sides with the Yugoslav regime of Milosevic which it supported militarily, and had opposed the NATO airstrikes against Serbia. Consequently, it deliberately kept its citizens ignorant of the human tragedy in Kosovo. Moreover, certain sections of society that were already "wound up" against the United States, saw in the bombing a deliberate desire to "humiliate" China. The outcome of this convergence was the inability of most Chinese to believe in the hypothesis of an accident, a hypothesis that their government also strongly denounced (and subsequently never accepted). Moreover the government was late publishing the official apologies given by the Clinton administration and by NATO, which, as soon as they were received, were called into question and considered by many demonstrators to be "lacking in sincerity".

In any case, this protest movement also constituted a turning point in nationalist expression in China, and in relations between the state and society. Firstly, this movement developed independently, giving rise to violence, which having been tolerated, was partly controlled in Peking, and much less so in Chengdu, where the American Consulate was burned to the ground. For about two weeks, the many 
foreigners resident in China were advised to reduce as much as possible their contacts with a local population which was galvanised against the Americans, and Westerners more generally. Hu Jintao, then the regime's second-in-command, was given the task of asking the demonstrators to put an end to their movement, apparently convincing them that the best way to avoid other "humiliations" was to work hard and contribute to the development and thus to the strengthening of their country. This was not a riskfree strategy, but it was successful in calming things down.

Secondly, the leaders of this movement mostly came from the universities, showing once more to what extent Chinese nationalism had become (once again) a weapon that allowed the elites and the future elites (the students) to express themselves and to influence the government. Moreover this movement shed light on the deeply emotional character of Chinese nationalism. Rather than expressing itself through constant pressure on the authorities or on foreigners, it manifests itself through moments of intense mobilisation, which can lead to surges of anti-Western violence. In 1999, there were no foreign casualties. But one cannot exclude such a possibility in the future, so punctuated is the history of Chinese nationalism, in its populist and primitive dimension, with aggression against foreigners. The anti-Japanese violence perpetrated over the last few years, and particularly during the demonstrations in the spring of 2005 , have shown that such an evolution remains possible.

At the same time, the excesses of this movement led to important divisions among Chinese nationalists. On the one hand these excesses brought the writers of popularising tracts closer to the best-known nationalist intellectuals of the "New Left", as well as to conservative Communist Party leaders opposed to China's accession to the WTO. Moreover the demonstrations in May 1999 gave them an opportunity to denounce the supposed concessions made by Zhu Rongji on the question during his journey to the United States the previous month. Fang Ning and Wang Xiaodong, the two main organisers of the opinion polls in 1994-1995, wrote with Song Qiang, one of the authors of China Can Say No, an equally anti-American sequel to that book, entitled China's Path in the Shadow of Globalisation (Quanqiu yinying xia de Zhongguo zhi lu). Published in November 1999, the book received the explicit support of Yu Quanyu, former Vice-President of the Chinese Human Rights Commission, directed by the archconservative Zhu Muzhi. On the other hand, the increasing power of populist nationalism worried certain intellectuals who had initially perceived in it a stabilising factor. In 1998, the journal Strategy and Management excluded Wang Xiaodong from its list of contributors. The events of 1999 furthered this development. For example, these events led Xiao Gonqin, an intellectual described as a neo-conservative during the 1990s, but in reality fairly liberal although a nationalist, to denounce the extremism and the emotional and destabilising character of this new movement, in his eyes the source of the failure of numerous reforms in China (including those of Kang Youwei) ${ }^{23}$.

41 Finally the nationalist mobilisation in May 1999 was a lesson for the leadership of the Chinese Communist Party, or at least for some of them. Having for ten years nourished and fed the nationalist feelings of society, the government in Peking realised that these were getting out of control and could not only reduce its margin for manœuvre in international matters, but eventually destabilise it. This is the reason why, after 1999, while not overtly suppressing "populist nationalism", the Chinese authorities sought for several years to direct it, gradually toning down, particularly from 2000-2001 onwards, a foreign policy strategy which had done more to build the perception of a 
Chinese menace, particularly in the United States and in Japan, than to satisfy the demands of the populist nationalists. In this respect 9/11 made the Chinese government's task easier. But the latter's attitude towards nationalism has remained deeply ambivalent, so central is this ideology to the survival of the present regime. Thus the relative prudence advocated by Jiang Zemin after the demonstrations in 1999 was clearly called into question by $\mathrm{Hu}$ Jintao in the spring of 2005 .

The anti-Japanese demonstrations in the spring of 2005

The anti-Japanese mobilisation in the spring of 2005 was of a kind that set certain limits, probably temporary but nonetheless real, to the emergence of any autonomous nationalist movement in the People's Republic. The question here is not to pass judgement on the moral grounds for the Chinese movement of protest against the visits paid by the Japanese Prime Minister to Yasukuni, or against the approval by the Minister of Education of school textbooks with revisionist tendencies: both of these problems, which give rise to equally negative reactions in South Korea for example, show beyond a doubt the massive ambiguity of the Japanese Right towards the period of the war. Neither is it to disregard the general context of the rise in anti-Japanese feeling within Chinese society, nourished from a tender age by the education system and by government propaganda but also connected with China's emergence onto the world scene and marked by numerous incidents over the last few years. The physical and verbal violence that surrounded the football matches between China and Japan, held in Chengdu and in Peking in the course of the Asian Cup during the summer of 2004, were a striking illustration of this.

Nevertheless, the dialectic between, on the one hand the mobilisation observed in China from March 2005, and on the other, the Peking government's offensive against a number of Japanese initiatives is too close to believe that the latter did not instrumentalise the former, and was very likely at its origin.

Indeed, what unleashed the Chinese Communist Party's campaign against Tokyo was the joint American and Japanese declaration on February 19th 2005 on security in the Far East, in which, among the many shared strategic objectives on display, there appeared the peaceful settlement of the question of Taiwan. Although insignificant because it added hardly any substance to previous commitments, this declaration nonetheless appeared at a difficult time, marked in particular by clearer military rivalry between China and Japan (sharpened by the intrusion of a Chinese submarine in Japanese territorial waters in November 2004), the lack of summit meetings between the two countries, because of Prime Minister Koizumi's repeated visits to Yasukuni, and dissension over the underwater gas deposits at Chunxiao, which lie in an area which is claimed by both countries.

In this context, the petition against Japan's candidacy for a permanent seat on the UN Security Council, which was launched at the end of February by the "Alliance to preserve the truth about the Sino-Japanese war", based in the United States, and then taken up by several Chinese websites which are tightly controlled by the Chinese government, could seem somewhat suspicious ${ }^{24}$. Although there is no tangible evidence that the authorities in Peking played any part in this initiative, the role they play in manipulating the debates taking place on the Internet unavoidably casts doubts on the spontaneity of this campaign ${ }^{25}$. This petition was enormously successful, with 22 million electronically-collected signatures within a month, and 40 million by the end of April ${ }^{26}$. Shortly after, in early March, two books by the liberal author Yu Jie, including 
The Iron and the Plough, which exhorted his compatriots to find out more about Japan before "hating" it, were withdrawn from the bookshops ${ }^{27}$.

A month later, at the beginning of April, several demonstrations broke out in various cities in China, denouncing both Japan's candidacy for the UN Security Council and its general attitude to its own past, particularly the approval by the Japanese Ministry of Education of a school textbook (which was distributed to $0.1 \%$ of pupils) which plays down the massacres committed in China during the war, and the visits to Yasukuni. China's claim over the Senkaku (Diaoyutai) islands was also brought up. First organised in Chengdu and Shenzhen on April 5th, these demonstrations reached Peking on April 9th, and then Shanghai on April 16th. In Peking, and especially in Shanghai, verbal and physical violence was committed against Japanese representations with the permission of the Chinese authorities, and, even in Shanghai, against shops that sold Japanese products and several Japanese people, without the police showing any clear determination to prevent these people from being beaten up $^{28}$. The verbally and physically destructive excesses which took place in Shanghai led the Communist Party leadership to bring a halt to the demonstrations it had allowed to go ahead, revealing its power to suddenly muzzle a nationalist movement which one might have thought had acquired a certain autonomy.

Admittedly, the authorities in Peking, while refusing to present an apology to the government in Tokyo for the damage caused to its embassy and consulates in China, decided under the pressure of international reaction-particularly Japanese-to prosecute those who had committed the violence, and to pay for repairs to the damaged buildings (at least in Shanghai). But information received after the events makes it possible to think that Public Security and the Communist Youth League, in other words the government, played a decisive role in setting off and organising the April demonstrations. Those responsible for these demonstrations were not the spontaneous representatives of an autonomous civil society, but the cadres of those organisations. Those who participated belonged either to the student community, which is to say the future elite of the country, or to the new educated middle classes, such as those that now live around Zhongguancun, the new business district located near the capital's universities ${ }^{29}$. A final point is that these demonstrations brought together a fairly limited number of participants (between 10,000 and 20,000), for a country supposedly unanimously hostile to Japan. The order given on April 19th by the Minister for Foreign Affairs, Li Zhaoxing, to stop the movement, was meekly obeyed by these temporary demonstrators and the boycott against Japanese products they had launched fizzled quickly away. In a way the failure of this campaign showed how little it was "popular" and above all how unrealistic, in a country whose trade with the nation which is the target of its invective reached 168 billion dollars in 2004, ranking it second among China's trading partners, after the United States (with 252 billion dollars according to American statistics).

One might well consider however, that the temptation for Hu Jintao and the present authorities in China to brandish the nationalist weapon and to manipulate society for reasons of foreign policy, in this case with the aim of preventing Japan from rising to the status of Asian Great Power, has not been without its dangers. It has revealed an unappealing and rather undemocratic facet of chinese society, and especially of its rising elites, who did not hesitate to resort to racist slogans (comparing the Japanese to pigs, for example) and physical violence in order to advance their cause. This 
temptation also allowed other, more anti-authoritarian forces, to interfere in the movement, particularly in Shanghai, revealing the potential for anti-government protest that exists in China.

The loss of control of the movement probably explains the editorial published in the paper Jiefang ribao (Liberation), Shanghai's official daily, which claimed to perceive a "plot" in the anti-Japanese demonstrations rather than a patriotic movement ${ }^{30}$. The renewed instrumentalisation of nationalism decided on by $\mathrm{Hu}$ Jintao also caused dissension within the Communist Party leadership. The article in Jiefang ribao was also a virtually transparent denunciation of Hu's strategy and of its deplorable effects on social and political stability, and on the business environment, particularly in a city where Japanese economic presence is very strong. This is why the article was not reprinted in the national press and, according to outside sources, why the leaders in Shanghai were scathingly criticised for having allowed it to be published ${ }^{31}$.

Hu's strategy also turned its back on several years of efforts by Chinese specialists on Japan (Ma Licheng, Shi Yinhong, Lu Zhongwei, etc.) to convince their government to improve relations with this important partner, which is also strongly nationalist, and less willing nowadays to yield to the pressures of its former victims, and whose regional ambitions, as these experts see it, will have to be taken into account in one way or another ${ }^{32}$.

51 However, this episode showed how useful nationalism is to the government, both in order to legitimise its domination over society and to further its interests on the international scene, and particularly in its regional environment, even if it means fuelling the syndrome of a Chinese menace in Japan and a negative image abroad. It also showed the limitations of the emergence of an autonomous populist nationalism whose existence no longer needs to be demonstrated but whose propensity for being manipulated by the government has also been proved.

Chinese nationalism and the new dialectic between the state and society

Since 1999 a complex interaction has appeared between government and society around the question of nationalism. Today the discussions about the theme of nationalism go far beyond international questions and tend to concern the legitimacy of the political regime and its ability to raise China to the rank of Number One World Power, however much this ambition may be a dream. Since the end of the 1990s, the growth of electronic communications and forums has favoured wider expression by society on political matters and particularly on nationalism ${ }^{33}$. Certain fora specialise in nationalist diatribes (such as Qiangguo [Strong Country], or Jianchuan zhishi [Knowledge of Warships]). These fora are tolerated, particularly because of the support they receive from certain leadership circles, but they are also used by the authorities, since they are seen as polls on the opinions of society and particularly on the opinions of the educated population with Internet access (there were about 100 million Internet users in 2005). However, the Chinese Communist Party remains particularly vigilant over the subversive uses some might be tempted to make of nationalist sentiment.

Nationalism and foreign policy

Today, questions of foreign policy are debated by a much larger number of Chinese, particularly in discussion forums and in intellectual journals, such as Strategy and Management, which was banned during the summer of 2004 for having published an iconoclastic article on the question of North Korea's nuclear programme ${ }^{34}$. 

compromise. interests.

This episode also highlights a greater diversification of opinion on foreign policy. In other words, even among the fora and journals that have served as carriers of nationalist ideas, these are far from dominating all the debates. On the contrary, some research tends to show that the emergence of an urban middle class has contributed to the moderation of society's nationalist sentiment ${ }^{35}$. The internationalisation of China and of its modes of consumption is doubtless not unconnected to this evolution.

Having said that, the Chinese government remains strongly tempted to instrumentalise nationalism, and particularly its populist component, above all where its relations with the United States and Japan are concerned.

Where the former is concerned, Taiwan continues to occupy an important place. More generally, the strategic role played by the United States in Eastern Asia and in the world, as well as its determination, perceived as imperial, to export its political system, its values and its mass culture, are the targets of denunciation by the Communist Party and by the nationalist sections of the intellectual elites which continue to irrigate Chinese society. It is a similar case with perception of Japan, which remains largely in thrall to trends from a past that is long gone. Thus the Chinese government persists in placing at the centre of bilateral relations the problems connected with the war, with the apologies and with the Yasukuni Shrine, even going so far as to mobilise the man in the street against the Japanese government.

Thus, Peking's policies towards America, Taiwan and Japan have become largely dependent on a "public opinion" which is manipulated by the most nationalist political and intellectual elites, and sometimes by the leadership of the Communist Party. The government uses it to strengthen its hand in its relations with Washington, Taipei and Tokyo. But it also finds itself constrained to use cunning and to conceal any flexibility under an intransigent and even aggressive discourse when it decides to reach a

The attraction of the United States for many Chinese, and the importance of the economic and human exchanges with Japan can be helpful for those within the government who strive to maintain the stability of these bilateral relations, both of which are essential to China $^{36}$. But nationalist pressure is likely to remain strong, and in conjunction with the temptation to instrumentalise it which is often present in official circles, will continue to influence China's foreign policy as a whole, including that towards neighbouring countries such as Russia, India or Vietnam, with which border problems have not been completely settled, or even towards the European Union, which still refuses to grant China the status of a market economy and sometimes raises its voice in protest against the most visible human rights violations in that country.

Nationalism and the stability of the regime

Chinese nationalists have often proclaimed that: "If Taiwan declares independence and the Communist Party does nothing, we will overthrow it!" This provocative statement sheds light on the link that has always existed in China between the legitimacy of a government and its ability to defend the fundamental national interests of the country. And in the eyes of the majority of mainland Chinese, or at least of the elites who have the right to speak in their name, the question of Taiwan is part of those fundamental

60 This relationship has led some reformers who favour the establishment of a democratic regime in China to also claim to be nationalists. This is particularly the case of $\mathrm{Wu}$ 
Guoguang, now a Professor at the University of Victoria in Canada, and of Ding Xueliang, a Professor at the Science and Technology University of Hong Kong. One can perceive behind this strategy a desire to avoid allowing nationalism to become the monopoly of conservative forces close to the Communist Party. This approach, which has been criticised by some Chinese reformers and democrats, such as Ma Licheng, a former journalist with the People's Daily, and Chen Yang, a journalist with Radio France International, because they see it as "killing freedom" and as being a source of tensions with the outside world, cannot be easily brushed aside ${ }^{37}$. This is also the reason why others theorists of an exit from authoritarianism, such as Zheng Yongnian, a Researcher at the University of Nottingham, seek to construct a "democratic nationalism" in opposition to the "ethnic nationalism" of the populist movement ${ }^{38}$.

61 But one can appreciate the difficulty of such an undertaking, so easily can the debates about nationalism be taken over by the country's most xenophobic and demagogic powers.

All in all, Chinese nationalism constitutes a more complex ideology than might appear at first glance. In fact, both within the Communist Party and in society, the various forms of nationalism examined here still exist, and will probably continue to cohabit in future. Associated with the Cultural Revolution, which was still very present in people's minds, populist nationalism was little in evidence in the 1980s. In contrast, from the middle of the following decade, its influence grew rapidly, concentrating its attacks on the United States and on Japan. Since it expresses a feeling of insecurity in the face of richer and more powerful countries, could this form of nationalism not decline as China sees its own power grow and its standard of living improve? Possibly. But for all that one cannot rule out the Party leaders and certain intellectuals of the New Left being tempted in the future, for political ends, to hive off into extreme nationalism the reservoir of frustration and discontent contained in Chinese society. Having said that, and despite the anti-Japanese demonstrations in April 2005, this form of nationalism is today less perceptible within Chinese society, and even among the elite as a whole, which is perhaps a sign of a positive development. Is this to say that the globalisation of the economy and society in China have already contributed to marginalising this trend of thought? Or is this decline to be attributed to the increase in "face" (mianzi), capable of washing away past "humiliations", that the country's economic successes have provided to society?

63 The game is not yet won, so loaded is the process with jolts and even social crises. Pandering to the nationalism in society while marginalising its populist and aggressive corruptions, "the path of peaceful emergence" advocated by $\mathrm{Hu}$ Jintao in 2004, had precisely the aim of reassuring China's partners, and avoiding the trap which pre-war Germany and Japan fell into. But the anti-Japanese violence which the same Hu Jintao tolerated in April 2005 showed that the Communist Party remains in part a prisoner of its old demons. The future of Chinese nationalism will depend heavily on the chinese elites and their ability to give society an image that is both independent and accurate, of the intentions of their country's main partners. There is no doubt that much will also depend on the way in which these partners manage this nationalism, and, without acceding to its unreasonable demands, find ways to provide it with balanced and persuasive answers. One obviously thinks of Japan, which has not managed to come to terms completely with its past. Lastly, much will also depend on the chinese authorities, and their ability to embark on real political reform. Only a genuine 
diversification of the Chinese political system will be capable of guaranteeing the reconciliation of Chinese society with its own history, independent access to information about the outside world, the marginalisation of populist nationalism and thus the irruption of a tolerant and democratic nationalism into Chinese society, which, reviving Yan $\mathrm{Fu}$, Sun Yat-sen and $\mathrm{Hu}$ Shi, will find ways to co-exist smoothly with the other nationalisms which the world, and particularly East Asia, have produced. As such an evolution remains unlikely in the foreseeable future, we have no choice but to remain vigilant and attentive to the various manifestations of Chinese nationalism.

Translated from the French original by Michael Black

\section{NOTES}

1. Zhao Suisheng, A Nation-State by Construction. Dynamics of Modern Chinese Nationalism, Stanford, CA, Stanford University Press, 2004, pp. 29-31. This is the idea taken up by Jia Qingguo of the University of Peking in his article, "Disrespect and Distrust: the external origins of contemporary Chinese nationalism", in a special dossier "The Limits of Chinese Nationalism" introduced by William A. Callahan, Journal of Contemporary China, Vol. 14, No. 42, February 2005, pp.11-21.

2. James Harrison, Modern Chinese Nationalism, Hunter College of the City of New York, Research Institute of Modern Asia, 1969, quoted by James Townsend, "Chinese

Nationalism”, in John Unger (ed.), Chinese Nationalism, Armonk, NY, M.E. Sharpe, 1996, p.2.

3. Ernest Gellner, Nations and nationalism, Cornell University Press, 1983; Eric

Hobsbawm, Nations and Nationalism since 1780: Programme, Myth, Reality, Cambridge University Press, 1992.

4. On the links between Chinese nationalism and the Han race, cf. Frank Dikötter, The Discourse of Race in Modern China, Stanford University Press, 1992.

5. Benedict Anderson, Imagined Communities: Reflection on the Origins and Spread of Nationalism, Verso, 1991.

6. Eric Hobsbawm, Nations and Nationalism since 1780, op. cit.

7. The work of Lucien Bianco illustrates this point in many ways, cf. Origins of the Chinese Revolution, 1915-1949, Stanford University Press, 1973. One is tempted to apply E. M. Foster's personalism to Chinese society: he used to say that if he had to choose between betraying his country and betraying a friend, he hoped he would have the courage to betray his country. (Dictionnaire de la pensée politique. Hommes et idées [A Dictionary of Political Thought. Men and Ideas] Paris, Hatier, 1989, p. 565).

8. Yves Chevrier, La Chine moderne [Modern China], “Que sais-je ?", Paris, PUF, 1983, p. 20.

9. Andrew Nathan, Chinese Democracy, New York, Knopf, 1985.

10. Jean-Philippe Béja, "Naissance d'un national-confucianisme ?" [The Birth of National Confucianism? Merci de faire référence à l'édition anglaise] Perspectives 
chinoises, No. 30, July-August 1995, pp. 6-11. Since he succeeded to Jiang, Hu Jintao has been tempted to strengthen this "Confucianist nationalism".

11. The Chinese government's recent decision to set up a sizeable network of Confucius Institutes abroad is part of this nationalist project.

12. Benjamin Schwartz, In Search of Wealth and Power: Yen Fu and the West, Cambridge University Press, 1964.

13. Cf. Chapter XVIII "Patriotism and internationalism" in Quotations from President Mao Tse-tung, Peking, Foreign Language Editions, 1966, pp. 193-198. Here he declares in particular: "We must beware of harbouring the slightest pride inspired by great power chauvinism and of ever becoming presumptuous after our victory in the revolution and certain successes obtained in the field of construction. Whether great or small, each nation has its strong and weak points". Directly inspired by the Leninist and Marxist tradition, this advice seems to have been long forgotten.

14. Peter Hays Gries, China's New Nationalism. Pride, Politics and Diplomacy, Berkeley, University of California Press, 2004.

15. Chen Yan, L'Eveil de la Chine. Les bouleversements intellectuels après Mao, 1976-2002 [China's Awakening; Intellectual Upheavals After Mao, 1976-2002], La Tour d'Aigues, Edition de l'Aube, 2002, pp. 151 and after.

16. Edward Friedman, "Chinese Nationalism, Taiwanese Autonomy and the Prospects of a Larger War", Journal of Contemporary China, Vol. 6, No. 14, pp. 5-32.

17. In particular the failure in 1993 of China's candidacy to host the 2000 Olympic Games, and the unexpected inspection by the Americans in the same year of the Chinese ship Yinhe, which was suspected-wrongfully-of transporting forbidden chemical products to Iran, two episodes which contributed largely to the discourse of all Chinese nationalists.

18. He Xin stated in 1992, for example: “Our country must start up the propaganda machine to denounce to the Chinese people the American determination to annihilate China, cultivate a mentality of hatred towards our enemies and form a centripetal national spirit", quoted by Chen Yan, L'Eveil de la Chine, op. cit., p. 158.

19. Wang Shan (pseudonym, Luo yi ning ge er), Di sanzhi yanjing kan Zhongguo, Taiyuan, Shanxi renmin chubanshe, 1994; cf. also Joseph Fewsmith, China Since Tiananmen. The Politics of Transition, Cambridge University Press, 2001, pp. 146-151.

20. Peking, Zhongguo shehui kexue chubanshe, 1996.

21. Michael Pillsbury, China Debates the Future Security Environment, Washington DC, National Defense University, 2000.

22. For a worthwhile analysis of the ambiguities and pluralities of this nationalist discourse, cf. Christopher R. Hughes, "Interpreting Nationalist Texts: a poststructuralist approach", Journal of Contemporary China, Vol. 14, No. 43, May 2005, pp. 247-267.

23. Xiao Gongqin, "The Kosovo Crisis and the Nationalism of Twenty-first-Century China”, in Jean-Philippe Béja and Jean-Pierre Cabestan (eds.), “The Responses of Intellectuals to the Challenges of the Twenty-first Century in China", Part II, Contemporary Chinese Thought, Autumn 2003, Vol. 35, No. 1, pp. 21-48 ; cf. also Fewsmith, China Since Tiananmen, op. cit., p. 217.

24. This initiative was reported in a very positive manner by the Chinese press, cf. China Daily, March 23rd 2005 (Internet).

25. Nanfang zhoumo (Southern Weekend), May 19 th 2005.

26. New York Times, April 1st 2005. 
27. BBC, March 30th 2005.

28. According to eyewitness reports, the police impassibly watched stone-throwing and other violence against the Japanese Embassy in Peking, and then after half an hour their leaders amiably told the demonstrators: "Comrades, you are getting tired! It's time to get back to your campuses". (Tongzhimen, nimen xinku le! Xianzai nimen huiqu xuexiao). Interviews, Peking, May 2005. Japanese TV stations repeatedly broadcast these attacks on their compatriots. Among the verbal excesses, slogans as "Death to the Japanese pigs!" were repeatedly shouted.

29. Interviews, Peking, May 2005; Reuters, April 9th 2005; AP, April 16th 2005.

30. Jiefang ribao, April 25th 2005.

31. Zhengming, May 2005, pp. 6-8. Another explanation put forward is that the Shanghai municipality deliberately allowed these excesses to take place in order to weaken $\mathrm{Hu}$ Jintao in the struggle which, since the compulsory retirement of Jiang Zemin in September 2004, has pitted the new government in Peking against the "Shanghai clique" formerly supported by Jiang and still represented at the top by Wu Bangguo, Zeng Qinghong, Huang Ju and Chen Liangyu, the Shanghai Party Secretary. However, there is no evidence to confirm the use of this "worst possible strategy".

32. Their views were published prominently in the journals Zhanluë yu guanli (Strategy and Management) and Xiandai guoji guanxi (Contemporary International Relations).

33. Joseph Fewsmith and Stanley Rosen, "The Domestic Context of Chinese Foreign Policy: does 'Public Opinion' Matter?”, in David M. Lampton (ed.), The Making of Chinese Foreign and Security Policy in the Era of Reform, Stanford University Press, 2001, pp. 151-187.

34. No. 4 (July-August 2004). In this article, the researcher Wang Zhongwen advised the United States to distance itself from the problem, and to let China assume its responsibilities, which is to say to influence Pyongyang itself, since its interests really lie in favouring the establishment of a de-nuclearised Korean peninsula.

35. Alastair Iain Johnston, "Chinese Middle Class Attitudes Towards International Affairs: Nascent Liberalization?”, The China Quarterly, No. 179, September 2004, pp. 603-628.

36. The idea of "positive nationalism" discussed by Chen Zhimin, takes these constraints into account and to some extent accords with the concept of "pragmatic nationalism", cf. Chen Zhimin, "Nationalism, Internationalism and Chinese Foreign Policy", Journal of Contemporary China, Vol. 14, No. 42, February 2005, pp. 35-53. On the relations between nationalism and foreign policy cf. also William A. Callahan, "Nationalism, Civilization and Transnational Relations: The Discourse of Greater China", Journal of Contemporary China, Vol. 14, No. 43, May 2005, pp. 269-289.

37. Chen Yan, L'Eveil de la Chine, op. cit., pp. 160 on.

38. Zheng Yongnian, Discovering Chinese Nationalism in China. Modernization, Identity, and International Relations, Cambridge University Press, 1999. 


\section{RÉSUMÉS}

While, for historical reasons, Chinese nationalism is in many ways specific, it has expressed, since the beginning of the modern era, which is to say since the Opium War of 1840, the profound insecurity of the Chinese elite. However, behind this feeling of insecurity, several forms of nationalism co-exist: an official nationalism inspired by communist ideology and the Communist Party's preoccupation with maintaining its monopoly of politics, which is similar to the modernising but authoritarian nationalism of many Chinese revolutionaries at the beginning of the twentieth century; a "primitive" and revanchist nationalism with racist tendencies, which is disseminated in society by the most xenophobic elements among the chinese elite; and a "pragmatic nationalism" which derives its legitimacy from the economic and social realities of China, without however rejecting foreign influence out of hand. Can this latter nationalism eventually give birth to a democratic nationalism, at once measured, open, and concerned with defending not only the interests of the Chinese nation, but also those of the men and women who belong to it? The anti-American demonstrations in 1999 and the anti-Japanese violence in the spring of 2005 highlight the difficulty of such an evolution, as well as the persistent temptation for the Chinese government to instrumentalise the only ideology that allows it to prolong its life expectancy. 